\author{
Ф.Р. Филатов, Н.С. Седых
}

\title{
ПСИХОЛОГИЧЕСКАЯ ПОМОЩЬ ПОСТРАДАВШИМ В РЕЗУЛЬТАТЕ ТЕРАКТОВ: КРИТИЧЕСКИЙ АНАЛИЗ И ПЕРСПЕКТИВЫ РАЗВИТИЯ
}

\begin{abstract}
Аннотация. В статье рассматриваются психологические особенности переживания террористических акций. Обсуждаются вопросы, связанные с переосмыслением жизненных ценностей и изменением социальных ориентиров вследствие пережитой травмы. Анализируются организационно-методические аспекты оказания психологической помощи и поддержки пострадавшим. В данном контексте обсуждается эффрективность разнообразных психотерапевтических практик и приёмов, используемых как при оказании экстренной психологической помощи, так и при работе, нацеленной на содействие в совладании с пролонгированными последствиями теракта. Обобщаются результаты академических исследований авторов и их практических наблюдений. Акцентируется внимание на стратегиях успешного совладания с травматическим стрессом и его последствиями. Анализируются конструктивные личностные и социальные стратегии, позволяющие преодолеть негативные последствия психической травмы, обрести новые смыслы, чели, позитивные перспективы. Подчёркивается необходимость консолидации усилий со стороны государственных и общественных структур, а также СМИ в целях создания единой системы профессионального межведомственного взаимодействия в ситуации теракта, а также обеспечения оперативного и своевременного устранения его последствий. Обсуждаются перспективы разработки единой междисииплинарной концептуальной модели, ориентированной на отбор, верификацию и совершенствование организационных, просветительских, психологических и психотерапевтических методов и методик, используемых, как в период оказания экстренной помощи, так и при проведении последующих реабилитационных мероприятий. Ключевые слова: терроризм, террористический акт, жертвы террора, психологическая помощь, психологическая поддержка, психотерапия, средства массовой информации, воздействие, последствия, профилактика. Review. The article is devoted to the psychological aspects of terroristic attacks experience. The problems related to the reinterpretation of life values and changing social guidelines as a result of the experienced trauma are discussed. In this context the organizational and methodological aspects of the psychological support and assistance to victims are analyzed. The efficiency of various psychotherapeutic practices and techniques used during the provision of emergency psychological aid and work aimed at coping with prolonged consequences of a terroristic attack is discussed. The authors summarize the results of their academic research and practical observations. The constructive personal and social strategies to overcome the negative effects of trauma and to find new meanings, goals and positive outlook are analyzed. The authors emphasize the need for specialized preventive activities of state and social institutions and mass media aimed at creating the integrated system of professional interdepartmental interaction and reducing the negative impact of terrorist attacks on public and individual consciousness. The article is also devoted to prospects for the development of a common interdisciplinary conceptual model focusing on the selection, verification and improvement of organizational, educational, psychological and psychotherapeutic methods and techniques which could be used during the periods of both emergency assistance and subsequent rehabilitation. Keywords: media, effect, act of terrorism, terrorism, victims of terror, psychological assistance, aftermath, psychological support, psychotherapy, prevention.
\end{abstract}

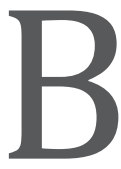

последние десятилетия террористические действия и порождаемые ими экстремальные ситуации достигают международных масштабов, изменяя облик современного мира, обозначая верхнюю границу или мыслимый предел заложенной в человеке деструктивности. Как показывают психологические исследования, травматические события, которые намеренно 
«сотворены» людьми, внезапны и сопряжены с насилием, имеют значительно большее разрушительное воздействие, нежели природные катастрофы [1]. Террористические акты бросают вызов не только устоявшемуся социальному порядку, но и мировоззрению, основанному на ценностях гуманизма и субъектности; они характеризуются сверхэкстремальным воздействием на психику человека, вызывая у него травматический стресс, психологические последствия которого нередко принимают форму посттравматического стрессового расстройства (ПТСР). ПТСР возникает, как отсроченная реакция на ситуации, сопряженные с серьёзной угрозой жизни, целостности или здоровью личности. Интенсивность стрессогенного воздействия в ситуациях, связных с угрозой существованию человека, бывает столь велика, что личностные особенности или предшествующие невротические состояния уже не играют решающей роли в генезе посттравматического стрессового расстройства [2]. Гибель людей, происходящая в результате терактов, является средством для достижения цели акции - создания обстановки страха, тревоги, паники, хаоса, чувства опасности, подстерегающей повсюду угрозы. К целям террористической акции относятся провоцирование и усугубление состояний социальной дезинтеграции [3, с. 23]. Следовательно, акт насилия, по мнению Р. Арона, целесообразно рассматривать, как террористический, только в том случае, когда его психологический эффект обратно пропорционален истинным физическим результатам [4]. Всемирная организация здравоохранения определяет террористические акты, как ситуации, характеризующиеся непредусмотренной, серьёзной и непосредственной угрозой общественному здоровью.

Отметим, что на сегодняшний день насчитывается более сотни различных определений терроризма. При этом отсутствует однозначная оценка природы современного терроризма и обозримых последствий этого явления. «Никого не должен сдерживать тот факт, что не существует «общей научной теории» терроризма, - пишет один из крупнейших современных исследователей У. Лакер. - Общая теория a priori невозможна, потому что у этого феномена много различных причин и проявлений» [цит. по: 5, с. 107].

В толковом словаре Даля терроризм трактуется, как «... устрашение смертными казнями, убийствами и всеми ужасами неистовства» [6, с. 4123]. В свою очередь, в словаре С.И. Ожегова понятие «тер- рор» определяется, как физическое насилие, вплоть до физического уничтожения, по отношению к политическим противникам [7, с. 707]. Отметим, что синонимами «террора» (лат. terror - страх, ужас) выступают слова «насилие», «запугивание», «устрашение» [8]. В словаре иностранных слов под редакцией И.В. Лехина террор понимается как применение насилия вплоть до физического уничтожения противника. «Терроризировать» значит «преследовать», «устрашать насилием, репрессиями»; «террористический» - «внушающий ужас, страх» [9, с. 456].

Иными словами, как следует из этимологии термина «терроризм», необходимым элементом, присутствующим в любой террористической акции, является устрашение политического противника, либо тех людей, которые выступают в роли непосредственных жертв терактов. Это нашло отражение в определении в Федеральном законе «0 противодействии терроризму» 2006 г. В соответствии с ним терроризм - идеология насилия и практика воздействия на принятие решения органами государственной власти, органами местного самоуправления или международными организациями, связанные с устрашением населения и / или иными формами противоправных насильственных действий [10].

Важно отметить, что терроризм в его нынешних формах и проявлениях стал возможен в условиях развивающегося общества риска. Общество риска, полагает автор этого термина, немецкий социолог У. Бек, - это «общество, чреватое катастрофами». Его нормальным состоянием может стать чрезвычайное положение. У. Бек, характеризуя особенности данного общества, указывал на состояние всеобъемлющего страха, все больше овладевающее людьми. Риск, по мнению исследователя, может быть определен, как «систематическое взаимодействие общества с угрозами и опасностями, индуцируемыми и производимыми модернизацией как таковой». Это приводит к формированию качественно новых «социально опасных ситуаций» и интенсификации глобальных угроз, к числу которых относится и угроза терроризма. Риски имеют тенденцию к усилению, так как они - продукт современных передовых технологий, к числу которых относятся и средства массовой коммуникации. В силу этого зачастую «неизведанные и неожиданные последствия приобретают характер господствующей силы» $[11$, с. 115,131$]$.

При рассмотрении организационно-методических аспектов оказания психологической помо- 


\section{Психология чрезвычайных ситуаций}

щи жертвам терактов, необходимо иметь в виду, что современный терроризм, развивающийся в условиях глобальной информатизации общества, имеет ряд отличительных признаков. Сегодня данная форма насилия рассчитана на массовое восприятие. Публичный, а зачастую даже демонстративный характер исполнения кровавых акций позволяет их организаторам усиливать эмоционально-психологическую напряженность в связи с террористическими угрозами и развивать страх перед лицом террора у широкого круга лиц [12]. Это во многом обусловлено тем, что вследствие тотального распространения информационных и цифровых технологий, социальный опыт людей складывается не столько на основе личных контактов, непосредственного восприятия событий, а преимущественно на основе сообщений и взаимодействий, опосредованных средствами массовой коммуникации. Отметим, что современный исследователь А.Э. Геворгян, рассматривая понятие, сущность и функции массовой коммуникации, подчёркивает, что сегодня это «система, в которой осуществляется взаимодействие, и одновременно это процесс взаимодействия; и способы общения, позволяющие создавать, передавать и принимать разнообразную информацию» [13, с. 9].

Как известно, СМИ информируют о террористических акциях зачастую в сенсационной форме, рассчитанной на острое эмоциональное восприятие. Режиссируя подобные сюжеты, их создатели широко используют принцип приоритетности. Тогда центральными темами новостного дискурса становятся безопасность, угроза миру, социальной стабильности, жизни, здоровью граждан. Это обеспечивает приоритетность информации по отношению к сообщениям о повседневной, будничной жизни. Психологическое влияние «угрожающих» сюжетов происходит, преимущественно, на эмоциональном уровне. Известно, что человеческие чувства социально опосредованы, что в силу механизмов эмоционального заражения и подражания люди легко воспринимают состояния и чувства, возникающие у других людей, порой неосознанно идентифицируясь с ними. При этом эмоциональная сопричастность способствует распространению по принципу социальной индукции сильных переживаний, заражая массы наблюдателей транслируемых сюжетов. Это обеспечивается и посредством часто применяемого приёма фасцинации, представляющего собой создание условий повышения эффективности воспринимаемого материала благодаря использованию сопутствующих фоновых воздействий, что усиливает заражение эмоциональным состоянием. Фасцинация проявляется, например, в напряженном тоне при сообщении информации о терроре. При этом эмоциональный заряд транслируемого сообщения нередко усиливается с помощью риторического приёма градации, когда комментатор повторяет доводы со всё возрастающим напряжением. Заметим, что, когда репортаж ведётся «с места событий» эмоциональное воздействие значительно усиливается влиянием, так называемого, эффекта присутствия [14]. Рассказываются непридуманные истории, демонстрируются реальные люди, их боль, страдание, горе, физические и моральные мучения, переживание утраты. В результате человек, наблюдающий за подобным сюжетом, оказывается «вырванным» из окружающей его действительности и её эмоционального фона и «вброшенным» в страшную реальность. Сконструированные медиа-образы порождают реальные эмоциональные и когнитивные реакции, способствуя развитию определённых психических состояний. «Если люди воспринимают некоторую ситуацию в качестве реальной, то она будет реальной и по своим последствиям», - утверждает У. Томас [цит. по: 15, с. 12].

Необходимо отметить, что с точки зрения рационально-эмоциональной поведенческой психотерапии (РЭПТ, направления когнитивной психотерапии, разработанного А. Эллисом), существует два типа когниций: дескриптивные и оценочные [16]. Дескриптивные когниции содержат информацию о реальности, о том, что человек воспринял в окружающем мире. Соответственно, угроза терроризма является дескриптивной когницией. В свою очередь, оценочные когниции отражают отношение к реально существующей угрозе пострадать от теракта. Подчеркнём, что с точки зрения основателя РЭПТ А. Эллиса, не объективные события сами по себе (терроризм) вызывают у человека положительные или отрицательные эмоции, а их внутреннее восприятие, оценка, интерпретация. Угроза терроризма относится к нерегулируемым стрессорам, т.е. к стрессорам, которые человек не способен предсказать и устранить. Это обстоятельство может повлечь за собой эмоциональный стресс, обусловленный восприятием и оценкой этой угрозы, как неотвратимой, настигающей любого в любом месте, а именно такой оценочный «шлейф» события часто и создается путём фасцинации и подобных приёмов. 


\section{Психология и психотехника 7(82) • 2015}

Итак, в условиях информационного общества цели террористического акта достигаются также путём психологического воздействия на лиц, не являющихся непосредственными жертвами насилия [17]. Безусловно, это вызывает ряд трудностей при определении круга жертв террора, нуждающихся в специализированной психологической помощи. Опираясь на опыт работы специалистов экстренных служб по ликвидации последствий терактов и иных катастрофических событий, В.А. Сосин предлагает следующую рабочую классификационную схему жертв терактов [1]. Эта классификационная схема содержит несколько категорий:

- Люди, которые серьёзно пострадали в эпицентре катастрофического события;

- Их семьи, близкие, друзья и знакомые;

- Сотрудники экстремальных служб и организаций, работа которых обязывает к прямому участию в опасных операциях по ликвидации последствий терактов;

- Члены местного сообщества, переживающие постигшее горе и идентифицирующие себя со страдающими жертвами;

- Люди с отклоняющимися психологическими и психическими поведенческими реакциями: так называемые возбудители напряжённости, которые склонны использовать ситуацию в своих собственных интересах;

- Другие люди, которые испытали потрясение.

Однако В.А. Сосин отмечает, что выделенные категории являются достаточно размытыми, и некоторые пострадавшие от теракта могут быть отнесены более чем к одной категории. Кроме этого, не все, попавшие в ту или иную категорию, будут нуждаться в одном и том же типе помощи, так как их потребности будут зависеть от ряда факторов - личностного восприятия травматического события, текущего состояния физического и психического здоровья, их психической выносливости, других стрессовых событий и т.п.

Вопросы о том, кого следует причислять к жертвам террора, как оказывать адекватную психологическую помощь и каковы критерии её эффективности, остаются сегодня открытыми и дискуссионными. Авторы данной статьи, опираясь, прежде всего, на опыт практической работы, предлагают собственный анализ данной проблематики [18]. Основой для совместного анализа стала работа Ф.Р. Филатова по оказанию психологической помощи пострадавшим от терактов в г. Волгодонске (взрыв жилого дома, 16.09.1999 г.), г. Беслане (захват заложников в школе № 1, 1.09.2004 г.), а также личный опыт переживания последствий теракта, произошедшего в г. Волгодонске, Н.С. Седых, их дальнейшее осмысление с позиций академической науки и социальной практики [19; 20].

Каковы последствия переживания экстремального опыта?

Говоря об индивидуальных и типологических реакциях на теракт, следует различать острые, хронические и отсроченные реакции. Острые реакции на теракт простираются в диапазоне от оцепенения, ступора, эмоциональной оглушённости до неконтролируемого аффекта, двигательной расторможенности, паники. Среди отсроченных реакций, проявляющихся спустя определённое время, выделяются навязчивые деструктивные образы и повторяющиеся ночные кошмары, подкрепляющие исходную травму, постоянно вторгающиеся в повседневную жизнь болезненные воспоминания о случившемся.

Например, у пострадавших от теракта в г. Волгодонске (взрыв жилого дома) наблюдался психопатологический феномен фиксированного времени, так называемый, синдром «пяти часов». Это связано с тем, что взрыв жилого дома произошёл в 5.50 минут по московскому времени. Проявления синдрома описаны главным врачом Психоневрологического диспансера г. Волгодонска К.Ю. Галкиным [21], на основании характеристик данного состояния, названных пострадавшими от этого теракта.

- «Внезапное, (как от толчка), регулярно повторяющееся пробуждение во время приблизительно соответствующее проведению теракта - от 5 до 6 часов утра»;

- «Пробуждение сопровождалось острым ощущением опасности и ожидания катастрофы»;

- «Окружающая обстановка комнаты в предрассветном сумраке казалось какой-то иной, наводящей тревогу, даже враждебной (дереализация)»;

- Собственное тело не слушалось, становилось напряжённым («зубы сцеплены, пальцы сжаты в кулаки»), в ряде случаев ощущение «ползающих мурашек (деперсонализация и парестезии)».

При этом некоторые проявляли активность: вставали, ходили, употребляли алкоголь, курили. Другие оставались лежать в кровати, успокаивая себя, старались думать о хорошем, обращались с молитвами к Богу и т.п. Однако по истечении времени совершения теракта наблюдалось уменьше- 


\section{Психология чрезвычайных ситуаций}

ние или исчезновение тревоги, напряжения, тахикардии. Большинство повторно засыпали.

Как показывают многочисленные исследования и, в частности, практический опыт авторов статьи, для людей, переживших теракт, характерны повышенная настороженность, тревожность, реакции избегания (любых стимулов, даже отдаленно напоминающих обстоятельства теракта). Зачастую происходит необъяснимое снижение мотивации в учебной или другой привычной деятельности, замкнутость, отчужденность, ангедония, снижение полового влечения, иррациональный и непреодолимый страх повторения теракта (вплоть до так называемых флэшбэков, внезапных погружений в травматический опыт со стиранием границы между прошлым и настоящим) [22].

Подчеркнем, что существенное влияние на переживание опыта теракта оказывает его интерпретация (в частности, религиозное осмысление), наличие более ранних непроработанных психотравм или актуальных кризисов, в том числе, возрастных, наличие навыков поведения в критических ситуациях, общий уровень культуры, жизненная философия пострадавшего, а также его способность вербализовать, т.е. словесно выразить пережитое. Соответственно, в работе с разными категориями пострадавших возникают разные трудности, которые нет смысла взвешивать и сопоставлять: всё определяется, скорее, индивидуальными особенностями и неповторимыми жизненными перипетиями. Каждый конкретный пострадавший, каждая конкретная семья травмированы по-своему и своим характерным способом переживают травму. В связи с этим не целесообразно разделять непосредственных жертв теракта и их родственников, так как обе категории подвергаются сильнейшему стрессу. Нередко страдания родителей или супругов, лишённых информации о жизни своих близких в момент теракта, находящихся в невыносимой неопределённости длительное время, встречающих препоны, грубость, безразличие на последующих этапах, требуют не менее серьёзной психологической работы и компенсации.

Анализируя опыт оказания психологической помощи, отметим, что в первые сутки после теракта проводится процедура, получившая название «дебрифинг» [19], - это определённым образом организованная и структурированная беседа с конкретными жертвами или дискуссия в группе пострадавших, призванная минимизировать вероятность развития у них посттравматического стрессового расстройства. Дебрифинг - одна из разновидностей кризисной интервенции, которая реализуется в групповой форме. Термин «дебрифинг» (англ. debriefing) заимствован из области военных технологий, где им обозначается обсуждение выполненного военнослужащим задания с целью сглаживания психологического стресса и обеспечения секретности полученной в ходе выполнения этого задания информации. Психологический дебрифинг преследует цели активной групповой проработки тягостных мыслей, переживаний и впечатлений от экстремального события (теракта), снижения возникшего напряжения и чувства изоляции, когнитивной оценки (переоценки) травматического опыта, а также мобилизации необходимых для совладания с ним индивидуальных и групповых ресурсов. В рамках дебрифинга последовательно и в атмосфере взаимной поддержки обсуждаются связанные с терактом факты, мысли, переживания и симптомы, что при условии своевременного проведения (первые двое суток) может принести ощутимый эффект.

Однако, как показывает практический опыт, гарантировать, что такая работа даст стопроцентный положительный результат, невозможно; по крайней мере, требуются дальнейшие кропотливые исследования эффективности методики и её усовершенствование.

Отметим, что в системе оказания помощи пострадавшим в результате террористической акции выделяют несколько направлений: медицинское, социальное и психологическое. Медицинская помощь включает в себя минимизацию тяжелых соматических последствий теракта (травм, физических повреждений, органических расстройств), а также психиатрическое обследование и при необходимости лечение. Социальная помощь охватывает различные аспекты реадаптации пострадавших в ситуации теракта, связанной с ним потери здоровья, работоспособности, имущества, и может включать правовую помощь и социальный патронаж. Психологическое направление призвано сгладить психологические последствия пережитой в результате теракта травмы или развившегося кризисного состояния. При этом общая организация помощи происходит с учётом следующих принципов:

1) своевременность (безотлагательность);

2) комплексность (помощь оказывается комплексно, путём интеграции различных реабилитационных процедур на основе единого системного представления о характере травмы); 


\section{Психология и психотехника 7(82) • 2015}

3) адекватность (выбранных форм и методов помощи специфике и тяжести переживаемой травмы);

4) согласованность, преемственность (все формы помощи должны быть соотнесены между собой и выстроены в единую закономерную последовательность);

5) поэтапность (каждый этап помощи задаёт определённый круг решаемых задач; реабилитация не ограничивается только скоропомощными мерами).

Однако, исходя из собственного опыта, отметим, что чаще помощь оказывается в чрезвычайном режиме. Другими словами, работа ведётся по живым следам экстремального события и, к сожалению, прерывается на первом же этапе, как только стихает общественный ажиотаж и интерес к событию в СМИ. В то же время эффективность психологической помощи и дальнейшей реабилитации пострадавших во многом определяется системностью и скоординированной работой разных служб: социальной, юридической, медицинской.

Безусловно, психологическая помощь должна быть своевременной, систематической и профессиональной. Вместе с тем, результативность помощи определяет комплексность, последовательность, поэтапность и завершённость, т.е. она должна охватывать полный цикл реабилитационных мероприятий. Максимальный результат приносит слаженное взаимодействие специалистов смежных помогающих профессий - психологов, врачей, социальных работников. Подчеркнём, что в таких трагических обстоятельствах помочь можно и нужно всем нуждающимся, так как помощь - это, в данном случае, не спасение, а психологическая поддержка, восстанавливающая жизненные ресурсы и продуктивные социальные отношения человека. Если специалист знает, как не навредить, и сам способен выдержать напряжение, возникающее в поле травматического опыта, ему, по крайней мере, удастся постепенно вывести пострадавшего из зоны отчуждения, где тот оказывается, не рассчитывая на какую-либо социальную поддержку.

Важнейшими условиями эффективного психологического сопровождения выступают эмпатия, безусловное принятие и уважение к личностной целостности пострадавшего, высокий уровень активности и включенности специалиста при разумном ограничении целей, фокусировка на актуальном травматическом опыте (без переключения на второстепенные задачи и прошлые, отдалённые во времени проблемные ситуации).

Обращаясь к вопросу эффективности взаимодействия специалистов разных помогающих профессий и ближнего окружения пострадавшего, подчеркнём, что врачам и младшему медицинскому персоналу в работе с жертвами теракта важно учитывать психологические факторы (эффекты психической травмы). Однако психологу необходимо осознавать границы своих профессиональных возможностей и ответственности, так как чрезмерное вовлечение в спасательскую деятельность может, не принеся результатов, обернуться травматизацией самого специалиста. В то же время от родственников требуется понимание, участие и терпение. Какой бы банальной и простой ни казалась эта истина, лучше всего лечит любовь, и вопрос о значимости любви, задаваемый Э. Фроммом, особенно актуален в контексте событий, фактически подрывающих веру в ценность отдельной личности и её жизни: «Как же человеку... не забыть, что он человек, неповторимая индивидуальность, тот, кому дарована только эта единственная возможность жить, жить со своими надеждами и разочарованиями, со своими печалями и страхами, со своей страстной потребностью в любви и ужасом перед пустотой и отчуждённостью?» [23, с. 31]. Найти ответ на данный вопрос очень важно для тех, кто пережил тяжёлое испытание, увидев смерть, беды и лишения. И сам человек, имеющий такой опыт, может помочь себе, изменив отношение к травматическому событию. То, что уже невозможно предотвратить, можно переосмыслить, например, как духовное испытание. Такое переосмысление в рамках психологической помощи достигается посредством приёмов так наз. «позитивной коннотации», позволяющей перефокусировать восприятие пострадавшего, сделав основные акценты на имеющихся у него и его окружении психологических pecypcax.

В этом контексте важно отметить, что тяжелые психологические последствия террористического акта, прежде всего, такие, как стрессовые расстройства, имеют тенденцию проявляться отсрочено. Соответственно, основная психотерапевтическая работа зачастую становится актуальной спустя, как минимум, два месяца после произошедшего. Однако, как правило, ни жертвы, ни их родственники не знают о том, что это закономерно, и не готовы к подобной динамике. Самая сложная работа начинается спустя несколько месяцев, ког- 


\section{Психология чрезвычайных ситуаций}

да симптомы и отсроченные реакции проявляются с особой остротой, затрудняя адаптацию, общение и повседневную жизнедеятельность пострадавшего человека. На этом этапе психологическая помощь требует установления глубоких доверительных отношений с психологом при поддержке ближайшего окружения пациента, его семьи. Реабилитация проводится в несколько этапов, носит комплексный характер и предполагает не только проработку травматического опыта теракта, но и повторную адаптацию к социуму, выработку навыков совладания со стрессом, построение позитивного образа будущего с конкретными жизненными целями и устремлениями. Это ярко иллюстрирует работа с последствиями террористического акта, произошедшего в г. Волгодонске, в результате которой у пострадавших произошло переосмысление ключевых социальных ценностей и изменение смысложизненных ориентиров. Многие из пострадавших пересмотрели свои жизненные стратегии, изменили векторы карьерного развития, отношение к семье как социальной ценности.

Важно отметить, что у пострадавших от теракта в г. Волгодонске наблюдалось снижение уровня социальной адаптивности и фрустрационной толерантности. Это проявлялось, например, в семейных и межличностных конфликтах, трудностях при вступлении в новые социальные контакты. На наш взгляд, фрустрационную толерантность в контексте социально-психологических последствий террористических акций, целесообразно рассматривать как порог терпимости к негативным эмоциональным переживаниям, вызванным травматическим стрессом [20]. Подчеркнём, что возможности успешного (конструктивного) преобразования травматического опыта теракта напрямую зависит от уровня развития когнитивного механизма оценивания, его гибкости; от способности человека взглянуть на сложную ситуацию с разных точек зрения. После психической травмы для субъекта меняются не только внешние обстоятельства, к которым надо заново приспособиться, но и собственный внутренний мир. Это обусловлено, прежде всего, тем, что под воздействием травмы происходят изменения в привычных когнитивных моделях. На субъективном уровне они находят отражение в переживаниях личностной изменчивости, зыбкости, нестабильности отношений человека с самим собой и с миром. В такой ситуации конструктивные стратегии личности реализуются в самоактуализации на основе экс- тремального жизненного опыта и предполагают отношение к нему, как к уникальному (экстраординарному), ценному и личностно значимому. Пережитое может при этом интерпретироваться как жизненный урок, духовное испытание, плодотворный экзистенциальный кризис и стимул к саморазвитию. Следуя такому подходу, пострадавшие начинают по-настоящему ценить жизнь, осознав её хрупкость, и стремятся к более продуктивной самореализации. Это позволяет оптимизировать творческий потенциал личности, обрести новые цели и перспективы и на их основе построить позитивный образ будущего.

Однако в специальной литературе традиционно последствия травмы описываются преимущественно в деструктивном ключе. У человека, обратившегося к таким источникам в поисках конструктивных решений, создаётся впечатление, что психотравма - «это приговор», её последствия чрезвычайно разрушительны и практически непреодолимы. Вероятно, выбор таких способов репрезентации последствий травматического стресса связан с опытом работы психологов с «трудными» клиентами, не отличающимися развитыми личностными, интеллектуальными и прочими ресурсами, а, возможно, и со стереотипным мышлением самих специалистов-психологов, описывающих подобные случаи. Однако такая картина кажется весьма неточной и несправедливой тем, кто имеет личный опыт переживания последствий психотравмы и успешного совладания с ними. Опираясь на собственный опыт и его анализ, подчеркнём, что ключевым ресурсом совладания выступает жизнестойкость личности. Кроме того, накопленный ранее культурный и психологический багаж личности, опыт преодоления ею других трудных жизненных ситуаций определяет развитие преобразовательной активности и является значимой предпосылкой самоактуализации на основе пережитого. Человек, занимающий активную жизненную позицию и ориентированный на саморазвитие, способен, переосмыслив случившееся, расширить поле субъективного опыта, обрести новые личностные смыслы, духовные ценности, социальные цели, веру в собственные силы и возможности. Человек, нашедший способы конструктивного совладания с последствиями травматического опыта, зачастую обнаруживает в себе скрытые ресурсы, приобретает социальную смелость, достигает поставленных целей и намечает новые векторы личностного, интеллектуального и духовного развития. 
В настоящее время накоплен обширный и ценный опыт психологической помощи пострадавшим от терактов. Огромную работу проводят в экстремальных ситуациях психологи МЧС, клинические психологи. Однако в каждой конкретной ситуации важно чётко определить место психологической службы в общей системе помощи, тот сектор, в котором она максимально эффективна.

Анализируя эффективные методы, приёмы и формы работы, отметим, что на первом этапе весьма продуктивным является дебрифинг, востребованы экспериментально-психологическое обследование жертв, работа с родственниками, в частности, просветительская и включающая элементы системной семейной терапии, а также все психологические технологии, направленные создание атмосферы защищённости и взаимоподдержки. Необходимо проведение групповых мероприятий с пострадавшими, их последующее психологическое сопровождение в течение ближайшего года после теракта.

На этапе пролонгированной психологической помощи может применяться широкий спектр методов и подходов. Их подбор определяется актуальными для данного этапа задачами, в числе которых:

1) помощь в совладании с травматическим стрессом и в выработке механизмов (навыков) его минимизации;

2) помощь в отреагировании и гармонизации связанных с терактом эмоций и переживаний, обеспечение катарсиса;

3) помощь в когнитивной переработке (переструктурировании, переосмыслении и переоценке) пережитого;

4) формирование позитивных представлений о будущем и реалистичных целей;

5) помощь пострадавшему в его социальной реадаптации, освоении новых жизненных стратегий и личностных ресурсов.

Для достижения обозначенных задач могут эффективно применяться методы поведенческой и когнитивной психотерапии, различные варианты аутогенного и релаксационного тренинга, суггестивные (трансовые) технологии, арт-терапия, библиотерапия, психосинтез и другие подходы. При этом помощь оказывается в режиме кризисной интервенции, согласно её базовым принципам.

По мнению авторов данной статьи, жизнестойкость личности выступает основным ресурсом совладания с психологическими и социаль- ными последствиями травматического события, соответственно, стратегии психотерапевтической помощи должны быть направлены не только на сглаживание конкретных негативных последствий теракта, но и на повышение общей жизнестойкости пострадавшей в результате теракта личности.

Вместе с тем, повысить эффективность психологической помощи возможно посредством развития и совершенствования не только имеющегося методического инструментария, но и организационных форм её оказания. Для решения столь широкого спектра задач и интеграции усилий специалистов на разных этапах требуется специализированная структура, тесно связанная как с соответствующими ведомствами и общественными организациями, так и со средствами массовой информации. Это продиктовано тем, что в снижении деструктивного психологического воздействия терактов на индивидуальное и массовое сознание велика роль СМИ. Известно, что страшнее любой конкретной угрозы неопределённость. Тогда слухи, как правило, заполняют некий информационный вакуум или рождаются на почве иррациональных страхов, закоренелых политических мифов, этнических стереотипов и предубеждений, которые вольно или невольно могут транслироваться журналистами, подпитываться самой подачей новостных сообщений. Кроме того, в эпоху глобальной информатизации сказанное и напечатанное слово обретает долгое, а, порой и иное, искаженное звучание в цифровой реальности, где появляются противоречивые комментарии пользователей Сети. И тем самым провоцируются новые эмоциональные всплески, продуцируются другие значения и смыслы, проникающие в социальное и психологическое пространство пользователей, воспринимающих информацию.

Учитывая сказанное, психологи могли бы сотрудничать с журналистами и обозревателями в плане повышения общей экологичности, эффективности и психологической безопасности доступных способов освещения теракта; они могли бы осуществлять психосемантический анализ новостных сообщений с целью сглаживания их побочного деструктивного эффекта без ущерба для гласности и достоверности. Поэтому важно, чтобы наряду с освещением разрушительных последствий теракта поступала конкретная информация о помощи, которая уже оказывается и может быть оказана, о том, где её можно получить, и что можно предпри- 


\section{Психология чрезвычайных ситуаций}

нять в конструктивном направлении в первые же часы после случившегося. Это требует разработки совместных проектов, консолидирующих усилия журналистского и психологического сообществ с целью разработки практических рекомендаций по организации информационного сопровождения, направленного на сглаживание деструктивного социально-психологического эффекта терактов.

\section{Список литературы:}

1. Соснин В.А. Психология современного терроризма. М., 2010.160 с.

2. Тарабрина Н.В. Практикум по психологии посттравматического стресса. СПб., 2001. 272 с.

3. Варканьянц Г.К. Терроризм: диагностика и социальный контроль // Социс. 2004. № 5.

4. Психология террористов и серийных убийц: хрестоматия / Под общ. ред. А.Е. Тарас. Мн., 2000. 346 с.

5. Современный терроризм: анализ основных направлений / Под общ. ред. А.Е. Тарас. Мн., 2000.

6. Даль В.И. Толковый словарь живого великорусского языка: современное написание cлов. M., 1998. (URL: http:// slovardalja.net/word.php?wordid=40157).

7. Ожегов С.И. Словарь русского языка. М., 1982.

8. Терроризм // Википедия (URL: http://ru.wikipedia.org/wiki/).

9. Лёхин И.В., Петров Ф.Н. Словарь иностранных слов. М., 2007.

10. URL: http://nac.gov.ru/content/3888.html.

11. Бек У. Общество риска. На пути к другому модерну. М., 2004.

12. Терроризм и контртерроризм в современном мире: аналитические материалы, документы, глоссарий: Научно-справочное издание / Под общ. ред. О.А. Колобова. М. 2003. 348 с.

13. Геворгян А.Э. Формирование общественного мнения средствами массовой коммуникации в современной России: Автореф. дис. ... канд. филос. наук. Краснодар, 2006.

14. Назаров М.М. Массовая коммуникация в современном мире: методология анализа и практика исследований. М., 2002. 312 c.

15. Андреева Г.М. Психология социального познания. М., 2004.

16. Психотерапевтическая энциклопедия / Под ред. Б.Д. Карвасарского. СПб., 2000.1001 с.

17. Современный политический экстремизм: понятие, истоки, причины, идеология, проблемы, организация, практика, профилактика и противодействие / Рук. авт. колл. Дибиров А. - Н.З., Сафаралиев Г.К. Махачкала, 2009. 640 с.

18. Седых Н.С. Психолог - на выезд. Срочно // Российская газета. Федеральный выпуск № 6340(68). C. 14. (URL: http:// www.rg.ru/gazeta/rg/2014/03/26.html).

19. Филатов Ф.Р. Принципы и методы психологической помощи жертвам экстремальных ситуаций // Северо-Кавказский психологический вестник. 2008. № 6/4. С. 92-96.

20. Седых Н.С. К вопросу о психологических последствиях терроризма // NB: Психология и психотехника. 2013. C. 101-130. (DOI: 10.7256/2306-0425.2013.1.229. URL: http://e-notabene.ru/psp/article_229.html).

21. Галкин К.Ю. Психические расстройства у лиц, перенесших террористический акт в г. Волгодонске 16 сентября 1999 года (клиника, диагностика, симптоматика): Автореф. дис. ... к. мед. н. М., 2004. 32 с.

22. Колодзин Б. Как жить после психической травмы. М., 1991. 289 с.

23. Фромм Э. Искусство любить. М., 2012.

24. Жалинский А.Э. Криминологическая характеристика терроризма в России // Национальная безопасность / Nota Bene. 2012. № 2. С. 22-29.

25. Мусаелян М.Ф. Квалифицирующие признаки террористического акта: толкование, квалификация, совершенствование (сравнительно-правовой анализ) // Журнал зарубежного законодательства и сравнительного правоведения / Journal of foreighn legislation and comparative law. 2014. № 1. С. 97-109.

26. Дубинкина К.А. Реализация концепции помощи развитию на примере деятельности Программы Развития ООН в России с 1990-х до середины 2000-х годов // Право и политика. 2014. № 7. C. 944-949. (DOI: 10.7256/18119018.2014.7.8828).

27. Mitchell J., Everly GS: Critical Incident Stress Debriefing (CSID). Ellicot City, Md, Chevron, 1995.

\section{References (transliteration):}

1. Sosnin V.A. Psikhologiya sovremennogo terrorizma. M., 2010.160 s.

2. Tarabrina N.V. Praktikum po psikhologii posttravmaticheskogo stressa. SPb., $2001272 \mathrm{s.}$

3. Varkan'yants G.K. Terrorizm: diagnostika i sotsial'nyi kontrol' // Sotsis. 2004. № 5.

4. Psikhologiya terroristov i seriinykh ubiits: khrestomatiya / Pod. obshch. red. A.E. Taras. Mn., 2000. 346 s.

5. Sovremennyi terrorizm: analiz osnovnykh napravlenii / Pod obshch. red. A.E. Taras. Mn., 2000.

6. Dal' V.I. Tolkovyi slovar' zhivogo velikorusskogo yazyka: sovremennoe napisanie slov. M., 1998. (URL: http://slovardalja.net/ word.php?wordid=40157).

7. Ozhegov S.I. Slovar' russkogo yazyka. M., 1982. 


\section{Психология и психотехника 7(82) • 2015}

8. Terrorizm // Vikipediya (URL: http://ru.wikipedia.org/wiki/).

9. Lekhin I.V., Petrov F.N. Slovar' inostrannykh slov. M., 2007.

10. URL: http://nac.gov.ru/content/3888.html.

11. Bek U. Obshchestvo riska. Na puti k drugomu modernu. M., 2004.

12. Terrorizm i kontrterrorizm v sovremennom mire: analiticheskie materialy, dokumenty, glossarii: Nauchno-spravochnoe izdanie / Pod obshch. red. O.A. Kolobova. M., 2003. 348 s.

13. Gevorgyan A.E. Formirovanie obshchestvennogo mneniya sredstvami massovoi kommunikatsii v sovremennoi Rossii: Avtoref. dis. ... kand. filos. nauk. Krasnodar, 2006.

14. Nazarov M.M. Massovaya kommunikatsiya v sovremennom mire: metodologiya analiza i praktika issledovanii. M., 2002. $312 \mathrm{~s}$.

15. Andreeva G.M. Psikhologiya sotsial'nogo poznaniya. M., 2004.

16. Psikhoterapevticheskaya entsiklopediya / Pod. red. B.D. Karvasarskogo. SPb., 2000. $1001 \mathrm{s.}$

17. Sovremennyi politicheskii ekstremizm: ponyatie, istoki, prichiny, ideologiya, problemy, organizatsiya, praktika, profilaktika i protivodeistvie / Ruk. avt. koll. Dibirov A. - N.Z., Safaraliev G.K. Makhachkala, 2009. $640 \mathrm{~s}$.

18. Sedykh N.S. Psikholog - na vyezd. Srochno // Rossiiskaya gazeta. Federal'nyi vypusk № 6340(68). S. 14. (URL: http://www. rg.ru/gazeta/rg/2014/03/26.html).

19. Filatov F.R. Printsipy i metody psikhologicheskoi pomoshchi zhertvam ekstremal'nykh situatsii // Severo-Kavkazskii psikhologicheskii vestnik. 2008. № 6/4. S. 92-96.

20. Sedykh N.S. K voprosu o psikhologicheskikh posledstviyakh terrorizma // NB: Psikhologiya i psikhotekhnika. 2013. S. 101-130. (DOI: 10.7256/2306-0425.2013.1.229. URL: http://e-notabene.ru/psp/article_229.html).

21. Galkin K.Yu. Psikhicheskie rasstroistva u lits, perenesshikh terroristicheskii akt v g. Volgodonske 16 sentyabrya 1999 goda (klinika, diagnostika, simptomatika): Avtoref. dis. ... k. med. n. M., 2004. 32 s.

22. Kolodzin B. Kak zhit' posle psikhicheskoi travmy. M., 1991. 289 s.

23. Fromm E. Iskusstvo lyubit'. M., 2012.

24. Zhalinskii A. E. Kriminologicheskaya kharakteristika terrorizma v Rossii // Natsional'naya bezopasnost' / Nota Bene. 2012. № 2. S. 22-29.

25. Musaelyan M.F. Kvalifitsiruyushchie priznaki terroristicheskogo akta: tolkovanie, kvalifikatsiya, sovershenstvovanie (sravnitel'no-pravovoi analiz) // Zhurnal zarubezhnogo zakonodatel'stva i sravnitel'nogo pravovedeniya / Journal of foreighn legislation and comparative law. 2014. № 1. S. 97-109.

26. Dubinkina K.A. Realizatsiya kontseptsii pomoshchi razvitiyu na primere deyatel'nosti Programmy Razvitiya O0N v Rossii s 1990-kh do serediny 2000-kh godov // Pravo i politika. 2014. № 7. S. 944-949. (DOI: 10.7256/1811-9018.2014.7.8828).

27. Mitchell J., Everly GS: Critical Incident Stress Debriefing (CSID). Ellicot City, Md, Chevron, 1995. 